\title{
Electronic Customer Relationship Management (E-CRM) Modeling on Micro, Small and Medium Enterprises (MSMEs) Banten
}

\author{
Vidila Rosalina \\ Faculty of Information \\ Technology - Universitas \\ Serang Raya \\ Jl. Raya Serang-Cilegon Km.5 \\ Taman Kopassus Serang \\ Banten Indonesia
}

\author{
Mulyanah \\ Faculty of Economy - \\ Universitas Sultan Ageng \\ Tirtayasa \\ Jl. Raya Jakarta Km.4 \\ Pakupatan Serang Banten \\ Indonesia
}

\author{
Abdul Malik \\ Faculty of Economy - \\ Universitas Serang Raya \\ Jl. Raya Serang-Cilegon Km.5 \\ Taman Kopassus Serang \\ Banten
}

\begin{abstract}
Micro Small and Medium Enterprises (MSMEs) Banten region are still largely managed by conventional methods, the touch of information technology has not been optimal. One of the modern business approaches is to pay attention to customer factors, not just before the transaction, but also after the transaction which is no less important. The Information Technology system used to manage customers with the purpose of increasing customer retention is called Customer Relationship Management (CRM). The existing CRM software is more oriented to large established companies, so it will cause some discrepancies when those are applied in MSMEs. This research tried to develop E-CRM software based on business needs of MSMEs in Banten by using local approach in order to facilitate user in its usage. The features in E-CRM will help MSMEs in implementing customer relationship management so as to enhance their competitiveness with other companies in maintaining the business they run and as a means of acquiring a wider new market. The approach used was using the model of 'localization' through the observations made on MSMEs business incorporated in the Association of Micro Small and Medium Entrepreneurs Indonesia (HIPMIKINDO) of Banten region. Identification and analysis of system requirements using the Zachman Framework was done in order to obtain a complete and comprehensive picture. The results of this research are expected to provide an overview of the characteristics of E-CRM modeling on MSMEs in Banten region.
\end{abstract}

\section{Keywords}

E-CRM, Localization, MSMEs, Zachman Frameworks.

\section{INTRODUCTION}

Marketing which is growing rapidly and understanding of consumer behavior becomes one of the strategies in the success of marketing the product [8]. The obstacle that most micro, small and medium enterprises (MSMEs) face is the difficulty of marketing their products and maintaining existing markets in addition to some other obstacles such as nonoptimal innovation, household finances mixed with industry finance and traditional management. Understanding and retaining customers become one of the strategies in the company's success. This is often a major obstacle to MSMEs in the middle of increasingly fierce competition. MSMEs need to maintain good relationships with customers and increase loyalty through knowledge and fulfillment of customer needs quickly and accurately. Electronic Customer Relationship Management (E-CRM) as an application of information technology will be able to overcome the problem because CRM's goal is to get the core concept of customer and put it in the framework of application of information technology utilization based on E-Commerce [9]. CRM can help MSMEs in developing new products based on a complete knowledge of customer desires, market dynamics and competitors. Thus, in order for MSMEs to get a better understanding of their customers and their needs, combination of data warehouse, data bank and help desk or call center is done. This research was conducted to develop CRM software on micro, small and medium enterprises. There are still a few MSMEs which have implemented this CRM even though many of them have realized that the utilization of information system becomes a necessity that can not be avoided by any business that wants to put itself in the front position in an industry. According to Danardatu (2003) CRM applications are now widely circulated in the market, mostly made by American and European companies that have already implemented CRM in their company. AMR Research reports several CRM software providers such as Siebel Systems, Microsoft, Clarify (Nortel Networks), PeopleSoft and Oracle are as market leaders. Meanwhile, professional CRM services companies as market leaders are Accenture, Art Technology Group, Cambridge Technology Partners, CSC, Deloitte Consulting, EDS, eLoyalty, Cap Gemini Ernst \& Young, IBM Global Services, KPMG Consulting and Price Waterhouse Coopers. This shows that CRM software providers are mostly foreign companies that may make MSMEs reluctant to utilize CRM applications into their business, because the high cost of these applications and foreign vendors are still unfamiliar with the preparation of unique small and medium business process. This is what motivated this research to help MSMEs in their business by designing CRM applications that are easy and affordable [2]. Thus the formulation of the problem in this research is "How is the modeling and implementation of Electronic Customer Relationship Management (E-CRM) application using Zachman Framework which is appropriate, easy and affordable for Micro Small and Medium Enterprises (MSMEs)?".

This paper will try to provide a new approach to the development of Electronic Customer Relationship Management (E-CRM) system tailored to the needs of existing business MSME in Banten by using local approaches to facilitate users in its use. The features in E-CRM will help MSMEs in implementing customer relationship management so as to enhance their competitiveness with other companies in maintaining the business they run and as a means of acquiring a wider new market. The approach used is using the model of 'localization' through observations made on MSMEs 
business incorporated in the Association of Micro Small and Medium Enterpreneurs Indonesia (HIPMIKINDO) of Banten region. System modeling uses the Zachman framework. The results of identification and analysis in this research are expected to be the basis in modeling and development of ECRM on MSME which is userfriendly in order to increase customer retention and build global marketing on MSME in Banten region.

Research on Customer Relationship Management (CRM) has been developed. Based on the literature study conducted, during the last four years there are several publications related to Customer Relationship Management (CRM) modeling that focused on Micro Small and Medium Enterprises (MSMEs) and Small and Medium Enterprises (SMEs).

In 2012 there is a publication of research on small and medium enterprises (SMEs) in Malaysia (Hashim, 2012), which found that $48.8 \%$ of small and medium entrepreneurs in Malaysia have implemented information systems to support their business processes. By utilizing information technology to manage its business performance, SMEs in Malaysia are able to increase their competitive advantage in facing increasingly fierce business competition [4].

In the same year 2012, there also found a research publication that shows how the concept of CRM can be implemented on small businesses to help improve and encourage the success of a business unit. Garcia, et al. (2012) offered a framework for implementing CRM based on case studies on MSMEs in one of the developing countries in Latin America, Mexico. Within the framework, Garcia et al. offered a CRM architecture for MSMEs that are divided into two parts: operational CRM and analytical CRM [3].

In Indonesia also found the publication of CRM model development research based on the culture of society and business model of SMEs in Indonesia. Sawitri et al (2012) in their research tried to develop CRM model which adapted to society culture and SME business model in Indonesia, and also paid attention to level of penetration of information technology in general [11].

In 2013, there was a publication found related to the development of E-CRM in MSMEs batik industry in Pekalongan. Nugraha et al (2013) in their research tried to develop web-based CRM software that adapts by using localization technique of batik industrial MSMEs in Pekalongan in applying customer relationship management so that it can improve its competitiveness with other companies in maintaining business that run and as a means to gain new wider market [5].

In 2015 there found publications related to the development of E-CRM on MSME producers educative game. Pramudiya et al (2015) developed E-Commerce with the implementation of CRM in it which can be a way out for Dolanan Puzzle in developing its business. The existence of E-Commerce as Dolanan Puzzle online store facilitates customers in looking for it [6].

Some of the above publications have developed CRM on SME/MSME which has been adapted to the culture and business processes of MSME in each country. However, those researches have not yet implemented CRM modeling using Zachman Framework to obtain a complete and comprehensive model picture of the MSME business process based on local culture.

\section{RESEARCH METHOD}

A preliminary study has been conducted to prepare this research by preparing several supporting theories about Micro Small and Medium Enterprises (MSMEs), Customer Relationship Management (CRM), Local Approach and Zachman Frameworks.

Definition of MSME is described in the law number 20 of 2008. Definition of MSME is divided into three, which are micro, small and medium enterprises. Micro Enterprise is productive business owned by individual and/or individual business entity fulfilling the criteria of Micro Business as regulated in this Law. Small Enterprise is a stand-alone productive economic enterprise, conducted by an individual or a business entity that is not a subsidiary or not a branch of a company owned, controlled, or becoming a part of the direct or indirect business of a medium-sized or large-scale business that meets the business criteria of Small business as defined in this Law. Medium Enterprise is a stand-alone productive economic enterprise, conducted by an individual or business entity that is neither a subsidiary nor a branch of a company owned, controlled, nor a share either directly or indirectly with a Small Business or a large business with a net worth or Annual sales proceeds as regulated in this Law.

MSME is one of the driving sectors of the Indonesian economy that can survive in facing the tight global business competition as it is today. The number of workers in the sector of MSME in early 2012 is almost 80 million people, this requires more attention to encourage MSME managers in improving business empowerment. There are several factors that influence the performance of MSMEs in maintaining business, including financing, human resources, market share, business climate, supporting facilities and infrastructure, and access to information [7]

There are several obstacles that can hamper the performance of MSMEs in maintaining business. Peni Sawitri, et al (2012) said that the constraints faced by MSMEs are the difficulty of marketing their products and maintaining existing markets, and the obstacles of innovation and financial management that have not been optimal because MSME business actors cannot survive. To be able to survive in maintaining its business, MSME is required to be able to start implementing various strategies in business development effort. Every MSME business actor is not only required to be able to create unique products but also must have the ability in terms of marketing the product. Without a well-supported marketing strategy, it is certain that MSME empowerment cannot grow rapidly [11].

In essence, CRM is a basic concept for attracting new customers, getting to know them well, providing them with exceptional service, and anticipating their wants and needs and retaining old customers to feel valued and needed by the company. When companies do these things well, increased revenue and profits tend to follow. Implementation of CRM on MSME in this research proposal will adopt existing CRM to be adapted to local requirement. Such a model is known as the local approach or localization. Internationalization and localization in computing means the adaptation of computer software, with different languages, regional differences and technical requirements of the target market. Internationalization is the process of designing software applications to be adapted to different languages and regions without engineering change. Localization is the process of customizing the internationalization software for a particular region or language by adding a specific local component and translating the text. Localization refers to the adaptation of 
product, application or document content to meet language, cultural and other requirements of a specific target market. Localization is often substantially more complex. This requires adjustments related to: numerical format, date and time, currency usage, keyboard usage, checking and sorting, symbols, icons and colors, text and graphics containing references to objects, actions or ideas that are in a particular culture, which may lead to misinterpretation. In some companies, CRM means creating bids to customers based on their behavior and demographic characteristics. Therefore it is necessary to understand localization in building CRM. In order for CRM to adapt to a local language is not just a matter of translating the text displayed on the screen. Consider this, for example, currencies used in certain countries (USD or \$ in the United States, GBP or $£$ in the UK), date and time formats (eg: 16 November 2009 will often be written as 2009/11/16 in the United States but in Indonesia, the format will be 16/11/2009) or number format (same number will be written slightly different in different country: 1,500.20 in America, while in Indonesia 1,500,20) [15].

According to Melissa A Cook (1996), John A Zachman in the late '80s introduced a framework to assist management in implementing two main things. The first thing is to separate the main components in information systems to facilitate management in planning and development. While the second thing is how to build a strategic plan from the most global level and conceptual to the technical implementation. In principle Zachman divided the information system into three major components, namely: Data, Process, and Technology which in its development into six main entities. A practitioner named John Zachman in the late '80s analyzed this and gave one of his solutions that is still relevant today to be used. To commemorate his name, this framework is called the Zachman Framework. Zachman Framework is a $6 \times 6$ matrix that represents the intersection of two classification schemes two-dimensional system architecture [1]

The Zachman Framework is expected to provide understanding of any particular aspect of a system at any point of view in system development. This tool can be useful for making decisions about changes and additions. The Zachman Framework contains six rows and six columns yielding 36 cells or aspects. The rows in the Zachman Framework include::

1. Scope: related to an executive summary for a planner (can be a stakeholder determining policies for an organization) who want an estimate of the size, cost and functionality of an organization.

2. Business model: showing entities and business processes, and how these entities and processes interact with each other.

3. System model: used by systems analysts who must determine the data elements and software functions that represent business models.

4. Technology model: regarding the constraints of tools, technology and materials.

5. Components: representing individual, independent modules that can be allocated to the contractor for the implementation process.

6. Working system: showing operational of the system [13].

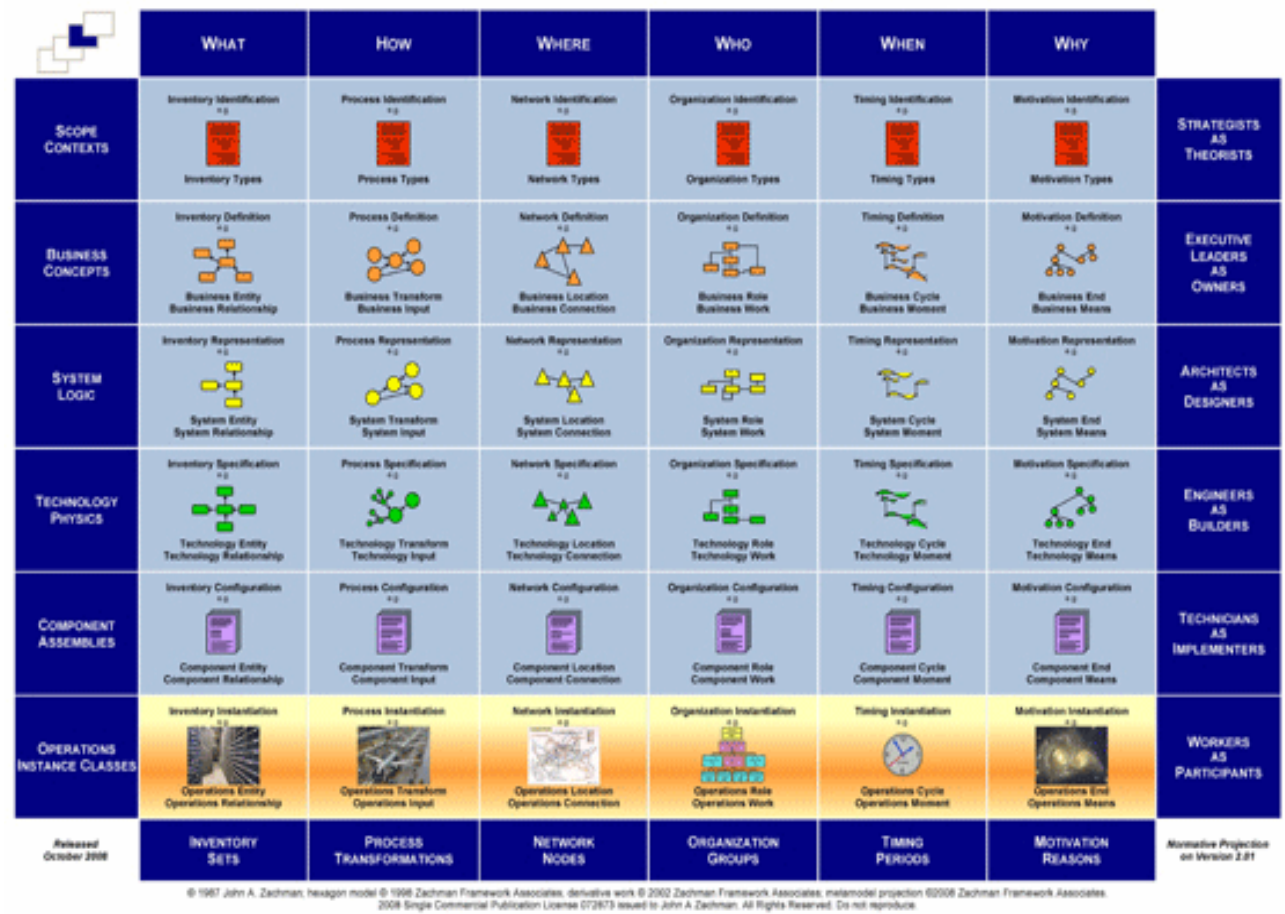

Figure 1: Zachman Framework

(http://zachmaninternational.com/index.php/home-article/13)

The columns in the Zachman Framework include:

1. Who: representing poeple's relationship in the company. The design of the organization of the company must relate to the allocation of work and the authority of structure and responsibility.

2. When: representing the time or event relationship that creates performance criteria and quantitative levels for 
company resources. This is useful for designing schedules, processing architectures, control architectures, and timing devices.

3. Why: describing the company's motivations. It shows goals and objectives, business plans, knowledge architecture, and knowledge design.

4. What: describing the entities involved in each company perspective. For example including business objects, system data, relational tables and definitions.
5. How: showing the functions in each perspective. For example including business processes, software application functions, computer hardware functions, and control loop languages.

6. Where: showing the locations and interconnections within the company. These include major geographical locations, separate sections within the logistics network, allocation of system nodes or even memory addressing in the system [14].

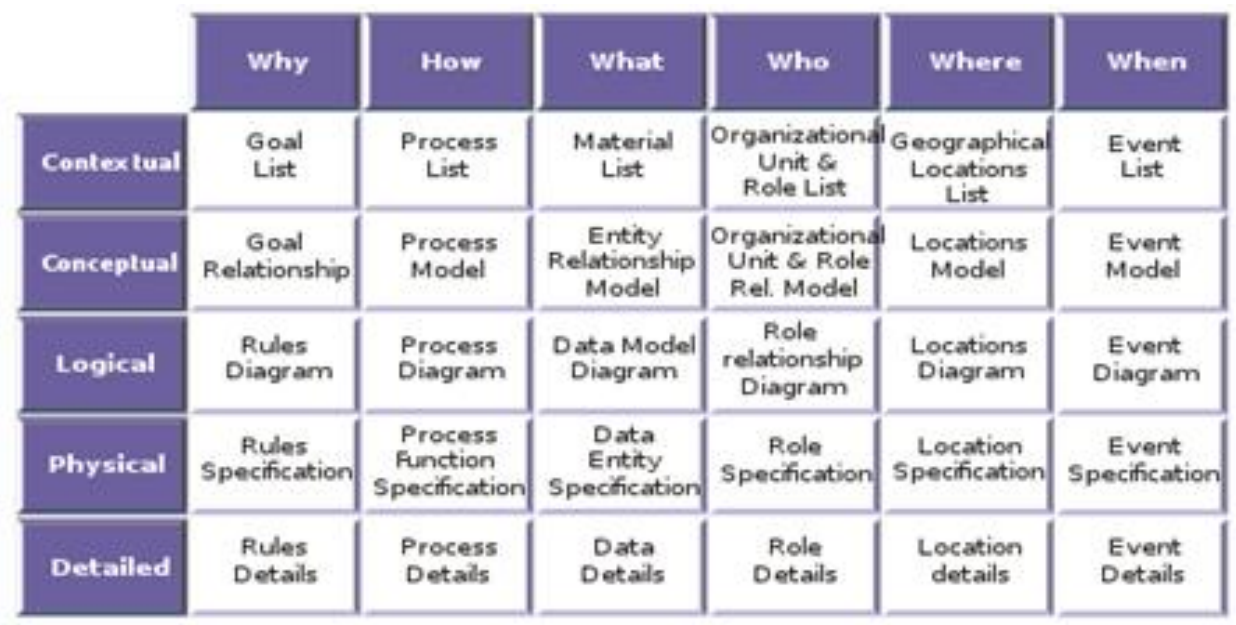

Figure 2: Zachman Framework Classification Matrix (Model of Cells Zachman Framework) (http://www.zachmanframeworkassociates.com/index.php/the-zachman-framework)

Zachman Framework does not provide specific models and architectures that can be used to provide a full explanation. Zachman Framework users are free to choose the tools that will be used to apply the model to be created.
Stages in the framework of thinking that was carried out in ECRM modeling research on MSMEs in Banten region is as follows:

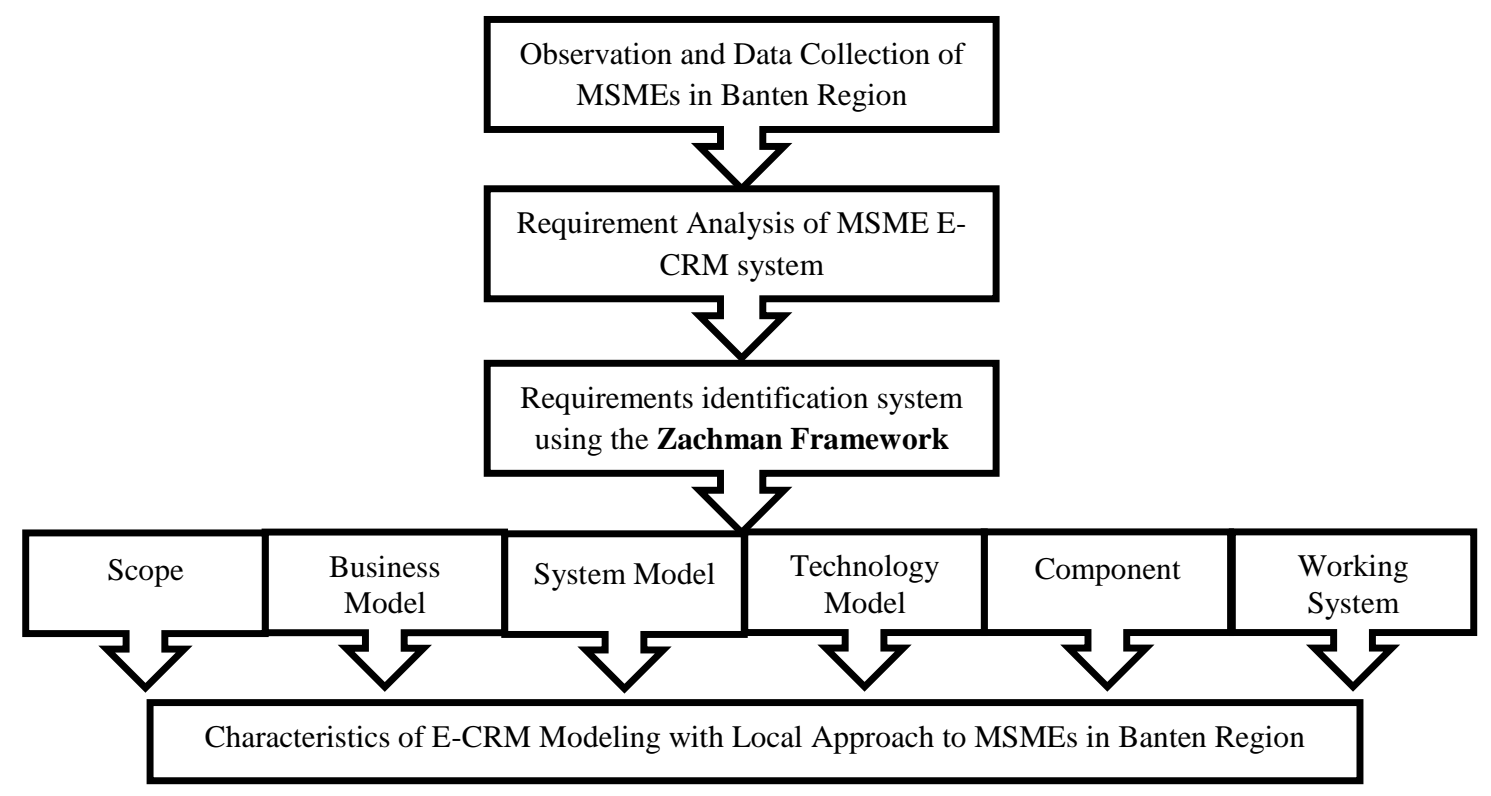

Figure 3. Framework of thinking.

\section{ANALYSIS AND RESULT}

System needs analysis of Electronic Customer Relationship Management (E-CRM) is based on the needs of existing MSMEs in Banten by using local approaches to facilitate users in its use. The features in E-CRM will help MSMEs in implementing customer relationship management so as to enhance their competitiveness with other companies in maintaining the business they run and as a means of acquiring a wider new market. The approach used is using the model of 'localization' through observations made on MSMEs incorporated in the Association of Micro Small and Medium 
Enterpreneurs Indonesia (HIPMIKINDO) of Banten region. System modeling uses the Zachman framework.

The following is the identification of E-CRM needs in MSMEs incorporated in HIPMIKINDO Banten and CRM comparison between large companies with MSMEs based on the classification matrix on Zachman Frameworks. Identification and comparison are seen from several perspectives as listed in table 1 below.

Table 1. Comparison of CRM between Large Company and MSMEs Banten Based on the classification matrix perspective on Zachman Frameworks

\begin{tabular}{|c|c|c|}
\hline Perspective & Large Company & MSMEs Banten \\
\hline 1. Scope & $\begin{array}{l}\text { Because of the } \\
\text { wide business } \\
\text { scope, CRM } \\
\text { applications are } \\
\text { equipped with } \\
\text { modern } \\
\text { application tools } \\
\text { such as E-mail, } \\
\text { E-Banking, } \\
\text { ATM, Credit } \\
\text { Card, Web and } \\
\text { others in order to } \\
\text { connect with } \\
\text { customers. }\end{array}$ & $\begin{array}{l}\text { Scope of business } \\
\text { is still limited so } \\
\text { connection with } \\
\text { customers only } \\
\text { relies on } \\
\text { telecommunications } \\
\text { tools such as } \\
\text { mobile phones } \\
\text { (SMS) or } \\
\text { smartphones } \\
\text { (BBM, WA, FB, } \\
\text { IG) because it feels } \\
\text { the easiest and do } \\
\text { not need a big } \\
\text { investment. }\end{array}$ \\
\hline $\begin{array}{l}\text { 2. Business } \\
\text { Model }\end{array}$ & $\begin{array}{l}\text { The } \\
\text { implementation } \\
\text { of a complex } \\
\text { CRM is needed } \\
\text { to respond to the } \\
\text { evolving } \\
\text { business needs. }\end{array}$ & $\begin{array}{l}\text { Implementation of } \\
\text { CRM with a simple } \\
\text { model because the } \\
\text { business needs are } \\
\text { still simple and the } \\
\text { transaction process } \\
\text { is also still simple. }\end{array}$ \\
\hline $\begin{array}{l}\text { 3. System } \\
\text { Model }\end{array}$ & $\begin{array}{l}\text { The CRM } \\
\text { system used is } \\
\text { already } \\
\text { integrated with } \\
\text { all existing } \\
\text { systems in the } \\
\text { company and } \\
\text { equipped with } \\
\text { data mining } \\
\text { functions. }\end{array}$ & $\begin{array}{l}\text { Not yet using an } \\
\text { integrated system } \\
\text { and customer data } \\
\text { obtained with the } \\
\text { contribution of } \\
\text { information } \\
\text { technology which is } \\
\text { not too complicated } \\
\text { and managed using } \\
\text { a database without } \\
\text { distributed. }\end{array}$ \\
\hline $\begin{array}{l}\text { 4. Technology } \\
\text { Model }\end{array}$ & $\begin{array}{l}\text { The technology } \\
\text { used is very } \\
\text { sophisticated, has } \\
\text { been } \\
\text { computerized } \\
\text { equipped with } \\
\text { modern network } \\
\text { infrastructure for } \\
\text { the application to } \\
\text { be always } \\
\text { reliable because } \\
\text { customer } \\
\text { information is } \\
\text { very important in } \\
\text { large companies. }\end{array}$ & $\begin{array}{l}\text { Have not been able } \\
\text { to use technology } \\
\text { like in big } \\
\text { companies. Most } \\
\text { have not been } \\
\text { computerized and } \\
\text { still rely on mobile } \\
\text { / smartphone in } \\
\text { dealing with } \\
\text { customers. }\end{array}$ \\
\hline
\end{tabular}

\begin{tabular}{|c|c|c|}
\hline 5. Component & $\begin{array}{l}\text { CRM features are } \\
\text { very complete } \\
\text { from before sales } \\
\text { to after sales, } \\
\text { equipped with } \\
\text { customer } \\
\text { analysis module } \\
\text { and customer } \\
\text { prediction } \\
\text { forward using } \\
\text { data mining/ } \\
\text { bigdata. }\end{array}$ & $\begin{array}{l}\text { The need for CRM } \\
\text { features in MSMEs } \\
\text { should } \\
\text { simplified } \\
\text { adapted to the } \\
\text { needs of MSMEs } \\
\text { and using local } \\
\text { language so as not } \\
\text { to complicate the } \\
\text { actors of MSMEs. }\end{array}$ \\
\hline $\begin{array}{l}\text { 6. Working } \\
\text { System }\end{array}$ & $\begin{array}{l}\text { Operational } \\
\text { CRM systems in } \\
\text { large companies } \\
\text { are complex and } \\
\text { use sophisticated } \\
\text { technology and } \\
\text { of course IT } \\
\text { teams are } \\
\text { required at the } \\
\text { time of } \\
\text { implementation. }\end{array}$ & $\begin{array}{l}\text { Operational } \\
\text { systems should be } \\
\text { simple and tailored } \\
\text { to the capabilities } \\
\text { of MSME resources } \\
\text { so they are easy to } \\
\text { implement, easy to } \\
\text { use and easy to } \\
\text { maintain by MSME } \\
\text { actors. }\end{array}$ \\
\hline
\end{tabular}

Based on the results of observations of MSMEs in Banten region identified in table 1 above, then the E-CRM development model with local approach needs to consider some characteristics as follows:

1. Its economic procurement is not burdensome for investment of MSMEs that tend to have small capital.

2. Using minimalist features that are often used MSME actors to avoid a complicated impression for the user.

3. Using the local language which is Indonesian so it is easily understood and understood by the MSMEs actors.

4. Easy to install, easy to implement, easy to use and easy to maintain.

5. An android-based interface; this gives a familiar feel for the users in general who have often come into contact with smartphones.

6. Applications do not always need an Internet connection, so it can work online or offline.

7. Applications are based on android so that MSME does not need to invest in computer procurement, but can use existing smartphone.

8. Utilize opensource solutions in order to avoid dependency and cost suppression.

9. In addition to connecting to customers using WA, BBM, FB Messenger, it can also be via phone and SMS.

10. Connected with a simple database backend, because in general the number of subscribers is relatively small and not too dynamic. 


\section{CONCLUSION}

From the discussion of the analysis and the results described above, it can be concluded that:

1. Identification of E-CRM needs in MSME in Banten region by using Zachman Frameworks which includes six perspectives (scope, model model, system model, technology model, component, and working system) can produce complete and thorough analysis.

2. Characteristics of E-CRM modeling of MSMEs in Banten region does not require features like in large companies but the features are made simple based on the needs of MSMEs and the local language are loaded to bring the userfriendly impression to the actors of MSMEs.

\section{REFERENCES}

[1] Cook, Melissa A. 1996, Building Enterprise Information Architectures, Prentice Hall

[2] Danardatu, Aloysius Heru. 2003, Pengenalan Customer Relationship Management, Ilmu Komputer.Com

[3] Garcia, I., Pacheco, C., Martinez, A. 2012. Identifying Critical Success Factors for Adopting CRM in Small: A Framework for Small and Medium Enterprises. Software Engineering Research, Management and Applications 2012, Studies in Computational Intelligence Volume 430, 2012, pp 1-15

[4] Hashim, R. 2012. Adoption of enterprise information system (EIS) in Malaysian small and medium enterprises (SMEs). Business, Engineering and Industrial Applications (ISBEIA), 2012 IEEE Symposium: 425 430.

[5] Localization, http://en.wikipedia.org/wiki/Internationali zatio_and_localization

[6] Nugraha, A., Dewi, I.N., Novianto, S. 2013. Desain Pengembangan Aplikasi Electronic Customer Relationship Management dalam Mendukung Strategi Pemasaran dan Pengelolaan Pelanggan UMKM , Konferensi Nasional Informatika (KNIF) ITB 2013.

[7] Pramudiya, E.H., Handarkho,Y.D., Rahayu, F.S. 2015. Pengimplementasian CRM Pada Pembangunan ECommerce untuk Usaha Mikro Kecil Menengah (Studi
Kasus: Dolanan Puzzle) Jurnal Buana Informatika, Volume 6, Nomor 4, Oktober 2015: 257-268.

[8] Rifa'i, B. 2013. Efektivitas Pemberdayaan Usaha Mikro Kecil dan Menengah (UMKM) Krupuk Ikan dalam Program Pengembangan Labsite Pemberdayaan Masyarakat Desa Kedung Rejo Kecamatan Jabon Kabupaten Sidoarjo. Kebijakan dan Manajemen Publik, 130-136.

[9] Rosalina, Vidila. 2013, Pemodelan CRM Pada Perusahaan Petrokimia menggunakan Zachman Framework, Jurnal ELECTRANS ISSN 1412-3762, Volume 12 No 2 (September 2013).

[10] Rosalina, Vidila., Natsir, M. 2014, Rancang Bangun Customer Relationship Manajemen (CRM) pada Perusahaan Petrrokimia Menggunakan Object Oriented Analisys and Design (OOAD), Prosiding Seminar Nasional Penelitian dan PKM (SNaPP) 2014: Sains, Teknologi dan Ilmu Kesehatan, Vol.4 no.1 th 2014 ISSN 2089-3582.

[11] Satzinger, John W., Robert B. Jackson, Stephen D Burd. 2009. Systems. Analysis and Design in a Changing World, Fifth Edition. Course Technology, Cengage Learning EMEA.

[12] Sawitri,P., Wulandari, L., Simri, L.I.W. 2012. CRM untuk UKM, Konferensi Nasional Sistem Informasi 2012, STMIK - STIKOM Bali 23-25 Pebruari 2012.

[13] Whitten, Jeffery, L., Bentley, Lonnie, D., Dittman, and Kevin, C., 2004, Metode. Desain dan Analisis Sistem (diterjemahkan oleh Tim Penerjemah ANDI), Edisi 6, Yogyakarta.

[14] Zachman, J.A., 2012, John Zachman's Concise Definition of the Enterprise Framework, http://www.zachman.com/aboutthe-zachman-framework.

[15] Zachman Frameworks, http://zachmaninternational.com

[16] Zachman Framework Classification Matrix, http://www.zachmanframeworkassociates.com/index.php /the-zachman-framework

[17] Zifa, Zachman Framework, http://www.zifa.com 